\title{
PENGUJIAN FAKTOR-FAKTOR YANG MEMBENTUK NIAT PEMBELIAN KONSUMEN SALADSTOP
}

\author{
Cynthia $^{1}$, Hetty Karunia Tunjungsari ${ }^{2 *}$ \\ ${ }^{1}$ Jurusan Manajemen Bisnis, Universitas Tarumanagara, Jakarta \\ Email: cynthia.115170398@stu.untar.ac.id, \\ 2 Magister Manajemen, Universitas Tarumanagara, Jakarta \\ Email: hetty@fe.untar.ac.id \\ *penulis korespondensi
}

\begin{abstract}
ABSTRAK
Tujuan dari penelitian ini adalah untuk menguji pengaruh penggunaan media sosial oleh konsumen, komunikasi oleh perusahaan, dan komunikasi oleh pengguna terhadap loyalitas dan kepercayaan. Selain itu, penelitian ini juga menguji pengaruh loyalitas dan kepercayaan terhadap niat pembelian, serta menguji adanya peran moderasi gender dalam pembentukan niat pembelian. Responden dalam penelitian ini adalah pelanggan SALADSTOP! di Jakarta dan orang-orang yang menggunakan media sosial. Metode convenience sampling digunakan dengan menyebarkan kuesioner online kemudian diolah menggunakan SmartPLS-SEM. Hasil dari penelitian ini adalah penggunaan media sosial dari konsumen, komunikasi oleh perusahaan, komunikasi oleh pengguna, loyalitas, dan kepercayaan, dapat mempengaruhi niat pembelian. Namun penggunaan media sosial dari konsumen tidak dapat mempengaruhi loyalitas. Gender juga tidak berpengaruh untuk mendukung atau memoderasi loyalitas terhadap niat pembelian dan juga kepercayaan terhadap niat pembelian.
\end{abstract}

Kata Kunci: Loyalitas, Kepercayaan, Niat Pembelian, Gender, Penggunaan Media Sosial

\begin{abstract}
The purpose of this study is to test the effect of consumer used of social media, company-generated communication, and user-generated communication to loyalty and trust, then loyalty and trust to purchase intention, and also to test gender as moderation between loyalty to purchase intention and trust to purchase intention. The population of this research is SALADSTOP! customers in Jakarta and people who use social media. The convenience sampling method is used by distributing online questionnaires and then processed using SmartPLS-SEM. The results of this study are consumer used of social media, company-generated communication, user-generated communication, loyalty, and trust, can affect purchase intention. But consumer used of social media cannot affect loyalty. Gender also didn't have any affect to support or moderating loyalty to purchase intention and trust to purchase intention.
\end{abstract}

Keywords: Loyalty, Trust, Purchase Intention, Gender, Social Media Use

\section{PENDAHULUAN \\ Latar Belakang}

Saat ini, semakin banyak konsumen yang memperhatikan unsur kesehatan dari makanan yang dikonsumsinya. Kebutuhan akan makanan sehat menjadi sangat penting untuk menjaga kesehatan konsumen. Konsumen didorong untuk mengubah pola konsumsi makanan menuju gaya hidup sehat, makanan yang tidak hanya mengandung nutrisi baik untuk tetap sehat, tetapi juga bebas dari bahan kimia seperti pengawet maupun zat aditif, mengandung gizi seimbang serta higienis. Untuk memastikan bahwa makanan yang dikonsumsinya telah memenuhi syarat kesehatan tersebut, banyak konsumen yang memilih untuk mengolah sendiri makanannya. Namun demikian, untuk alasan kepraktisan dan kemudahan dalam menjalani kehidupan seharihari, tidak sedikit pula konsumen yang memilih untuk membeli makanan siap konsumsi di restoran tertentu. Berbagai olahan makanan sehat saat ini dapat dengan mudah diperoleh konsumen. Restoran yang menyajikan makanan sehat, bahkan supermarket yang menyediakan makanan sehat siap saji dapat ditemukan di sejumlah kota besar di Indonesia. 
SALADSTOP! Merupakan salah satu restoran yang menyediakan hidangan salad dan berbagai hidangan yang baik untuk kesehatan. Bermula dari pendirian bisnis pertama di Singapura di tahun 2009, sekarang SALADSTOP! telah tersebar di berbagai negara di dunia, seperti: Singapura, Hong Kong, Vietnam, Malaysia, Jepang, Korea, Indonesia, dan Spanyol. SALADSTOP! Juga menjadi gerai pertama dan terbesar di Asia yang menyajikan healthy fastfood. Di Indonesia SALADSTOP! cukup populer di masyarakat dan memiliki beberapa gerai yang terletak di Jakarta.

Sebagai restoran yang menyediakan makanan sehat, SALADSTOP! memiliki cukup banyak pesaing sejenis, sebut saja Burgreens, Blue Terrace, The Roots Salad Bar, Greenery, Serasa Salad Bar, dan masih banyak restoran cepat saji lainnya yang menyediakan sajian serupa. Bagaimana kemudian SALADSTOP! dapat terus mempertahankan posisinya di pasar? Penelitian ini ditujukan untuk menguji faktor-faktor yang membentuk niat pembelian konsumen SALADSTOP! Dengan memahami faktor-faktor tersebut, diharapkan SALADSTOP! dapat menyusun strategi untuk terus mempertahankan konsumennya dan berkembang di masa mendatang.

Niat pembelian atau purchase intention merupakan perilaku penting dari perilaku-perilaku yang dimiliki konsumen (Yadav et al., 2013). Namun demikian, niat pembelian ini adalah kecenderungan subyektif yang dimiliki konsumen untuk membeli sebuah produk, yang dapat menandakan indikator utama perilaku konsumen (Hill, 1975). Produk yang baik adalah produk yang terjaga secara kualitas sejak dibuat hingga sampai di tangan konsumen (Tunjungsari \& Ivanko, 2019). Dengan kualitas yang baik, niat pembelian dapat muncul.

Kepercayaan atau trust merupakan faktor lain yang dapat membuat seseorang memutuskan untuk membeli sebuah produk. Kepercayaan memiliki peran dalam menjaga hubungan dari konsumen dengan penjual. Kepercayaan dibutuhkan untuk meningkatkan keputusan seseorang. Selain kepercayaan, loyalitas pelanggan terhadap sebuah merek juga dapat meningkatkan niat seseorang untuk membeli. Loyalitas pelanggan adalah komitmen yang dipegang teguh untuk membeli kembali atau berlangganan produk/layanan yang disukai secara konsisten di masa depan (Oliver, 1999).

Di era digital, kepercayaan dan loyalitas pelanggan dapat dibangun melalui media sosial. Di Indonesia, penggunaaan sosial media mencapai 56\% dari jumlah keseluruhan populasi masyarakatnya (Wearesocial, 2019). Di tahun 2020, Wearesocial mendapatkan pengguna media sosial meningkat menjadi 59\% dari total populasi. Platform media sosial yang paling sering digunakan adalah Youtube, Whatsapp, Facebook, Instagram, dan Twitter. Banyaknya pengguna media sosial di Indonesia membuka peluang untuk mempromosikan merek di media sosial.

Gender atau jenis kelamin dapat menjadi indikasi pengaruh satu variabel ke variabel lain, seperti gender mana yang lebih tertarik dan gender mana yang lebih menggunakan. Gender digunakan untuk membedakan laki-laki dan perempuan. Dalam pemasaran suatu produk, ada beberapa jenis yang hanya berfokus ke konsumen laki-laki, ataupun hanya berfokus ke konsumen perempuan. Sering kali juga pesan komunikasi diciptakan condong pada salah satu gender untuk lebih menarik niat pembelian kelompok gender tertentu. Penelitian ini akan menguji apakah terdapat perbedaan niat pembelian dari kelompok laki-laki dan perempuan. Dengan memahami ada tidaknya perbedaan antar kelompok gender, SALADSTOP! dapat menyusun pesan komunikasi pemasaran yang lebih spesifik dan sesuai dengan target audiens. 


\section{Loyalitas dengan Niat Pembelian}

Mainardes \& Cardoso (2019:4) mendefinisikan loyalitas sebagai munculnya niat untuk membeli sebuah produk atau menggunakan merek atau perusahaan yang sama di masa depan, terlepas dari semua efek dan upaya yang ada untuk menghasilkan perubahan. Adapun Thakur (2016:153) menyebutkan bahwa loyalitas adalah niat atau keinginan pelanggan untuk membeli dari penjual yang sama atau merek yang sama lagi dan merupakan hasil dari keyakinan bahwa nilai yang diterima dari penjual atau merek tersebut lebih tinggi daripada nilai yang tersedia dari alternatif lain. Pada penelitiannya mengenai penggunaan media sosial terhadap niat pembelian di toko secara langsung, Mainardes dan Cardoso (2019) menunjukan bahwa loyalitas memiliki pengaruh yang positif terhadap niat pembelian. Hameed \& Kanwal (2018) menemukan bahwa loyalitas memiliki pengaruh yang positif terhadap niat pembelian produk kosmetin. Adapun Panda et al. (2019) menemukan bahwa dalam konteks sustainability di India, loyalitas memiliki pengaruh yang positif terhadap niat pembelian. Berdasarkan penelitian-penelitian terdahulu, diajukan hipotesi berikut:

H1: Loyalitas pelanggan memiliki pengaruh yang positif pada niat pembelian

\section{Kepercayaan dan Niat Pembelian}

Menurut Chiu et al., (2009:205) kepercayaan adalah suatu keyakinan utama yang berhubungan dengan kompetensi dan integritas. Gefen (2000:1002) juga mengatakan kalau kepercayaan merupakan keyakinan seseorang pada ekspetasi positif dari apa yang akan dilakukan situs website, asal, kasus, dan pengalaman terdahulu. Mainardes dan Cardoso (2019) menemukan bahwa kepercayaan memiliki pengaruh yang positif pada niat pembelian. Issock et al., (2019) membuktikan bahwa kepercayaan memiliki efek yang positif pada niat pembelian. Sementara itu, Irshad et al. (2019) meneliti tentang motivasi konsumen di sosial media di dan membuktikan bahwa kepercayaan memiliki pengaruh positif terhadap niat pembelian. Berdasarkan penelitianpenelitian tersebut, disusun hipotesis berikut:

$\mathbf{H}_{2}$ : Kepercayaan memiliki pengaruh yang positif pada niat pembelian

\section{Kepercayaan dan Loyalitas}

Mainardes \& Cardoso (2019) juga menemukan adanya pengaruh positif kepercayaan pada loyalitas. Penelitian Esenyel \& Girgen (2019) mendapatkan hasil yang sama, yaitu pengaruh yang positif terhadap variabel kepercayaan dan loyalitas. Adapun Ebrahim (2019) meneliti dalam konteks pemasaran media sosial di Mesir dan menemukan bahwa kepercayaan memiliki pengaruh yang positif terhadap loyalitas pelanggan. Dengan demikian, disusunlah hipotesis sebagai berikut:

H3: Kepercayaan memiliki pengaruh positif pada loyalitas pelanggan

\section{Consumer Use of Social Media dan Kepercayaan}

Menurut Shanmugam et al., (2016) penggunaan media sosial oleh konsumen merupakan platform sosial menawarkan tingkat interaksi antara pengguna dan perusahaan yang telah mengubah saluran komunikasi tradisional dan menghasilkan peningkatan konsumen yang mencari informasi di media sosial daripada melalui media tradisional. Sementara itu, Esenyel \& Girgen $(2019 ; 1498)$ menyatakan bahwa penggunaan media sosial adalah jaringan sosial yang didukung oleh aplikasi komputer disarankan untuk berdampak pada bisnis dan kehidupan pribadi. Mainardes \& Cardoso (2019) terdapat pengaruh positif dari penggunaan media sosial oleh konsumen pada kepercayaan. Lebih lanjut, Esenyel \& Girden (2019) yang meneliti tentang media sosial digunakan sebagai pembangun hospitality di hotel-hotel, juga menemukan adanya pengaruh positif penggunaan media sosial oleh konsumen pada kepercayaan. Kwon et al. (2020) meneliti faktor-faktor yang mempengaruhi kepercayaan dan loyalitas konsumen restoran di AS 
dan Korea dan menemukan bahwa penggunaan media sosial oleh konsumen dapat memiliki efek yang positif pada kepercayaan pelanggan. Dari penjelasan tersebut, diajukanlah hipotesis berikut: H4: Penggunaan media sosial memiliki pengaruh yang positif terhadap kepercayaan

\section{Consumer Use of Social Media dan Loyalitas}

Terdapat penelitian yang membuktikan bahwa penggunaan media sosial oleh konsumen memiliki hubungan yang positif dengan loyalitas pelanggan (Mainardes \& Cardoso, 2019). Penggunaan media sosial oleh konsumen juga dinyatakan memiliki pengaruh positif pada loyalitas (Esenyel \& Girgen, 2019). Sementara itu, Kwon et al. (2020) menemukan bahwa penggunaan media sosial oleh konsumen dapat memiliki efek yang positif pada loyalitas pelanggan. Dengan demikian, hipotesis selanjutnya dalam penelitian ini adalah:

Hs: Penggunaan media sosial memiliki pengaruh yang positif pada loyalitas pelanggan.

\section{Company-Generated Communication dan Kepercayaan}

Menurut Alalwan et al. (2017) komunikasi dari perusahaan merupakan jejaring sosial mengacu pada penggunaan media sosial sebagai sarana untuk berhubungan dengan orang-orang. Duffett (2015) mendefinisikan komunikasi dari perusahaan sebagai kecepatan komunikasi dan banyaknya sumber informasi menarik pemasar untuk beralih dari media tradisional ke media sosial untuk menciptakan kesadaran dan merangsang preferensi konsumen terhadap merek. Mainardes \& Cardoso (2019) dalam penelitiannya membuktikan bahwa komunikasi dari perusahaan memiliki pengaruh yang positif pada kepercayaan. Dalam konteks pemasaran media sosial, Ebrahim (2019) mendapatkan hasil bahwa komunikasi dari perusahaan dengan menggunakan pemasaran media sosial memiliki pengaruh yang positif pada kepercayaan. Adapun Kwon et al. (2020) membahas tentang penggunaan media sosial untuk promosi atau periklanan oleh perusahaan dan menemukan adanya efek yang positifnya pada kepercayaan. Hipotesis yang diajukan kemudian adalah:

H6: Komunikasi dari perusahaan memiliki pengaruh yang positif pada kepercayaan

\section{Company-Generated Communication dan Loyalitas}

Duffett (2015) mendefinisikan komunikasi dari perusahaan sebagai kecepatan komunikasi dan banyaknya sumber informasi menarik pemasar untuk beralih dari media tradisional ke media sosial untuk menciptakan kesadaran dan merangsang preferensi konsumen terhadap merek. Menurut Ebrahim (2019) komunikasi dari perusahaan dengan pemasaran media sosial memiliki pengaruh yang positif pada loyalitas pelanggan. Company-Generated Communication membantu perusahaan untuk membuat, memelihara, dan memperkuat hubungan mereka dengan target konsumen (Poulis et al., 2018).

Hipotesis berikutnya adalah:

H7: Komunikasi dari perusahaan memiliki pengaruh yang positif terhadap loyalitas pelanggan.

\section{User-Generated Communication dan Kepercayaan}

Gangadharbatla (2008) mendefinisikan komunikasi dari pengguna sebagai pertumbuhan komunitas online dan akses media sosial mendukung peningkatan komunikasi yang dihasilkan oleh pengguna di media sosial, yang merupakan wahana perbincangan tentang merek dan opini konsumen. Lebih lanjut, Schivinski \& Dabrowski (2016) menjelaskan bahwa dalam komunikasi dari pengguna, lebih pada masyarakat umum yang menciptakannya dibandingkan pemasar, dan terutama didistribusikan di internet, tanpa maksud komersial dan tidak dikendalikan oleh perusahaan. Manardes \& Cardoso (2019) menemukan bahwa komunikasi antara pengguna media sosial memiliki pengaruh positif pada kepercayaan. Dalam penelitiannya, Sohail et al., (2020) 
mendapatkan hasil bahwa interaksi di media sosial sesama pengguna dapat mendapatkan efek yang positif pada kepercayaan. Dengan demikian hipotesis berikutnya adalah:

Hs: Komunikasi dari pengguna media sosial memiliki pengaruh yang positif pada kepercayaan

\section{User-Generated Communication dan Loyalitas}

Richter \& Koch (2007) menjelaskan bahwa komunikasi dari pengguna merupakan sebuah interaksi yang terjadi di aplikasi dan platform media sosial online yang dapat menjadikan masyarakat secara umum menjadi pemasar tanpa maksud komersial dan juga tidak dikendalikan oleh perusahaan serta menjadi wahana perbincangan tentang merek dan opini konsumen. Sohail et al., (2020) yang meneliti pengguna media sosial di Saudi Arabia membuktikan adanya efek positif interaksi dari pengguna media sosial pada loyalitas produk atau merek. Nyadzayo et al. (2019) menemukan bahwa komunikasi word-of-mouth dapat memberikan efek positif pada loyalitas. Hipotesis selanjutnya adalah:

H9: Komunikasi dari pengguna media sosial memiliki pengaruh yang positif pada loyalitas pelanggan

\section{Loyalitas dan Kepercayaan Mempengaruhi Niat Pembelian dengan Dimoderasi Gender}

Menurut Benson et al. (2018) gender memoderasi pengaruh kepercayaan pada niat pembelian konsumen di Inggris. Ditemukan bahwa wanita memiliki niat pembelian yang lebih tinggi dibanding laki-laki. Beccera \& Badrinaryanan (2013) membuktikan bahwa di AS, kepercayaan pada merek merek dapat mempengaruhi niat pembelian yang dimoderasi oleh gender. Sementara itu, Jeon \& Jeong (2016), menemukan bahwa loyalitas mempengaruhi niat pembelian konsumen di AS, dan kelompok laki-laki memiliki niat pembelian yang lebih tinggi dibanding kelompok perempuan. Berdasarkan penelitian-penelitian tersebut, diajukan hipotesis sebagai berikut:

H10: Kepercayaan dan loyalitas pelanggan memiliki pengaruh yang positif terhadap niat pembelian dengan moderasi gender.

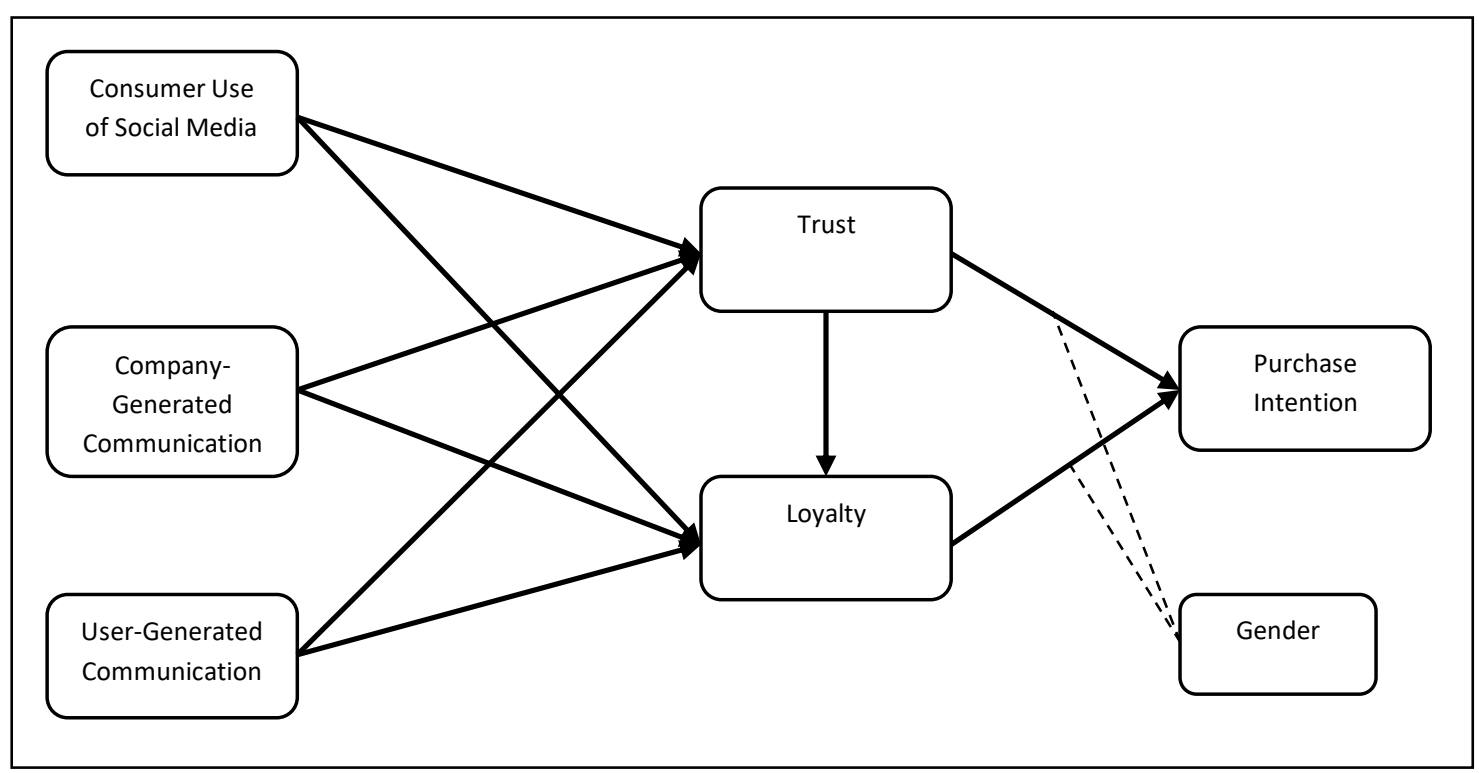

Gambar 1. Model Penelitian 


\section{METODE PENELITIAN}

Teknik pengumpulan sampel yang digunakan dalam penelitian ini adalah non-probability sampling teknik convenience sampling. Data diperoleh dengan melakukan survey online menggunakan Google Form. Sampel merupakan konsumen restoran SALADSTOP! di Jakarta. Terdapat sebanyak 224 responden yang berpartisipasi dalam survey online, tetapi hanya sebanyak 203 responden yang datanya dapat diolah lebih lanjut dikarenakan tidak sesuai dengan kriteria yang ditentukan. SmartPLS-SEM digunakan untuk mengolah data penelitian. Dari total responden yang didapat, sebanyak 113 (56\%) wanita dan 90 (44\%) pria. Rentang usia terbanyak adalah yang kelompok usia 20-25 tahun sebanyak 142 responden (70\%) dan latar belakang pekerjaan responden mayoritas pelajar/mahasiswa dengan jumlah 143 responden (62\%). Indikator pengukuran variabel dalam penelitian ini dapat dilihat pada Tabel 1.

Tabel 1. Indikator Pengukuran Variabel

\begin{tabular}{|c|c|c|}
\hline Variabel & Indikator & Sumber \\
\hline $\begin{array}{l}\text { Penggunaan Media Sosial } \\
\text { oleh Konsumen }\end{array}$ & 10 Indikator & Rapp et al., (2013) \\
\hline Komunikasi dari Perusahaan & 5 Indikator & $\begin{array}{c}\text { Schivinski \& Dabrowski } \\
\text { (2016) } \\
\text { Ebrahim (2019) }\end{array}$ \\
\hline Komunikasi dari Pengguna & 5 Indikator & $\begin{array}{c}\text { Schivinski \& Dabrowski } \\
\text { (2016) } \\
\text { Kwon et al. }(2020)\end{array}$ \\
\hline Loyalitas & 6 Indikator & $\begin{array}{l}\text { Palmatier, Scheer, \& } \\
\text { Steenkamp (2007) }\end{array}$ \\
\hline Kepercayaan & 4 Indikator & $\begin{array}{c}\text { Srivastava, Chandra, \& } \\
\text { Theng (2010) }\end{array}$ \\
\hline Niat Pembelian & 3 Indikator & $\begin{array}{l}\text { Schivinski \& Dabrowski } \\
\text { (2016) }\end{array}$ \\
\hline
\end{tabular}

\section{Hasil Analisis Validitas}

Analisis validitas dengan menggunakan teknik SEM terbagi menjadi dua. Yang pertama, menurut Hair et al. (2011), Validitas Konvergen atau Convergen Validity dianggap valid apabila nilai Average Variance Extracted (AVE) yang didapat memiliki nilai lebih dari $0.50(>0.50)$. Lalu yang kedua, menurut Henseler et al. (2016), Validitas Diskriminan atau Discriminant Validity dilihat dari pendekatan HTMT (Heteroit-Monotrait Ration) dan nilai baik yang dapat digunakan adalah lebih kecil daripada 1.

\section{a. Validitas Konvergen}

Uji validitas konvergen dilakukan dengan melihat AVE masing-masing konstruk, model dinyatakan telah memenuhi validitas konvergen yang disyaratkan jika masing-masing konstruk telah memiliki nilai AVE diatas $0.5(>0.5)$.

Tabel 2. Hasil Analisis Validitas Konvergen

\begin{tabular}{lc}
\hline \multicolumn{1}{c}{ Variabel } & $\begin{array}{c}\text { Average Variance } \\
\text { Extracted (AVE) }\end{array}$ \\
\hline Penggunaan Media Sosial oleh Konsumen & 0.611 \\
Komunikasi dari Perusahaan & 0.677 \\
Komunikasi dari Pengguna & 0.689 \\
Loyalitas & 0.676 \\
Kepercayaan & 0.661 \\
Niat Pembelian & 0.746 \\
\hline
\end{tabular}


Pada hasil AVE diatas, seluruh variabel memiliki nilai diatas 0.5 , hal ini menunjukan bahwa setiap indikator telah memenuhi syarat dan ketentuan validitas konvergen berdasarkan analisis AVE.

\section{b. Validitas Diskriminan}

Hasil uji diskriminan pada penelitian ini bertujuan untuk mengetahui nilai setiap variabel laten dengan variabel lainnya. Pada Tabel 3 merupakan hasil validitas diskriminan yang diolah menggunakan perangkat lunak SmartPLS.

\begin{tabular}{cccccc}
\multicolumn{6}{c}{ Tabel 3. Hasil Analisis Validitas Diskriminan } \\
\hline & CC & SM & LY & TR & PI \\
\cline { 2 - 6 } SM & 0.824 & & & & \\
LY & 0.835 & 0.770 & & & \\
TR & 0.870 & 0.826 & 0.845 & & \\
PI & 0.792 & 0.793 & 0.799 & 0.881 & \\
UC & 0.821 & 0.744 & 0.780 & 0.811 & 0.787 \\
\hline
\end{tabular}

Pada Tabel 3 ditunjukkan bahwa nilai HTMT lebih kecil daripada $1(<1)$ atau kurang dari 0.9 $(<0.9)$, sehingga dapat dikatakan nilai tersebut telah memenuhi syarat dan ketentuan validitas diskriminan. Sehingga dapat dikatakan bahwa model ini sudah valid karena telah memenuhi syarat validitas diskriminan.

\section{Hasil Analisis Reliabilitas}

Reabilitas digunakan untuk mengukur suatu kuesioner yang merupakan indikator dari variabel (Ghozali, 2016). Kuesioner dapat dikatakan valid apabila jawaban dari responden tersebut sama atau konstan dari waktu ke waktu. Penelitian ini menggunakan nilai dari cronbach's alpha atau Composite Reliability. Nilai cronbach's alpha dikatakan reliabel jika nilai yang dihasilkan diatas atau sama dengan 0.70 (Henseler et al., 2016).

Hair et al. (2019) mengatakan kalau composite reliability dapat dikatakan valid atau diterima jika lebih dari 0.7 (>0.7), tetapi jika nilainya 0.6, ini juga masih bisa diterima. Ini adalah uji reabilitas konsistensi internal.

Tabel 4. Hasil Analisis Reliabilitas

\begin{tabular}{lcc}
\hline \multicolumn{1}{c}{ Variabel } & Cronbach Alpha & Composite Reliability \\
\hline Penggunaan Media Sosial oleh Konsumen & 0.929 & 0.94 \\
Komunikasi dari Perusahaan & 0.881 & 0.913 \\
Komunikasi dari Pengguna & 0.887 & 0.917 \\
Loyalitas & 0.904 & 0.926 \\
Kepercayaan & 0.829 & 0.886 \\
Niat Pembelian & 0.83 & 0.898 \\
\hline
\end{tabular}

Dari hasil analisis reliabilitas pada Tabel 4 diatas dengan menggunakan pendekatan cronbach alpha dan composite reliability, menunjukan bahwa indikator yang digunakan dalam pengukuran setiap variabel penelitian ini adalah reliabel. Dikarenakan hasil dari kedua metode diatas sudah memenuhi syarat. Yaitu diatas atau sama dengan $0.70(>0.70 / \pm 0.70)$ untuk cronbach alpha dan diatas 0.7 (>0.7) untuk composite reliability. 


\section{HASIL DAN PEMBAHASAN}

\section{Hasil Analisis Data}

Setelah melakukan uji outer model, selanjutnya akan dilakukan analisis inner model untuk menguji hubungan dari variabel ke variabel lain yang sesuai dengan hipotesis. Pengolahan analisis data pada penelitian ini menggunakan perangkat lunak SmartPLS 3.0. Analisis data yang akan dibahas pada poin ini adalah analisis inner model. Analisis ini terdiri dari uji $\mathrm{R}^{2}$ (R-Square), $\mathrm{Q}^{2}$ (Predictive Relevance), dan Goodness of Fit (GoF).

\section{Hasil Uji $\mathbf{R}^{2}$ (R-Square)}

Uji ini digunakan untuk mengetahui persentase kontribusi antara variabel independen (Penggunaan media sosial, komunikasi dari perusahaan, komunikasi dari pengguna, loyalitas, dan kepercayaan), variabel dependen (Niat pembelian), dan variabel moderasi (Gender). Berikut merupakan hasil uji $\mathrm{R}^{2}$ yang dapat dilihat pada Tabel 5.

Tabel 5. Hasil Uji R-Square

\begin{tabular}{lcc}
\hline \multicolumn{1}{c}{ Variabel } & R-Square & Keterangan \\
\hline Loyalitas & 0.662 & Sedang \\
Kepercayaan & 0.649 & Sedang \\
Niat Pembelian & 0.591 & Sedang \\
\hline
\end{tabular}

Pada hasil uji diatas, niat pembelian yang merupakan variabel dependen mendapatkan hasil sebesar 0.591, yang berarti sebesar 59.1\% dari variabel dependen dapat dijelaskan oleh variabelvariabel yang diteliti (Penggunaan media sosial, komunikasi dari perusahaan, komunikasi dari pengguna, loyalitas, dan kepercayaan).

Hasil pengujian variabel dependen memiliki pengaruh yang sedang karena memiliki nilai lebih dari 0.50 . Hasil dari pengujian loyalitas dan kepercayaan juga memiliki pengaruh yang sedang karena lebih dari 0.50, tetapi tidak melewati 0.75 (kuat).

\section{Hasil Uji Q⿻2 (Q-Square)}

Pengujian Q-Square dalam penelitian ini digunakan untuk mengetahui bagaimana konstruk dari variabel-variabel dalam penelitian ini mengukur model penelitian yang telah terbentuk sebelumnya. Uji Q-Square dalam penelitian ini menggunakan metode blindfolding dengan perangkat lunak SmartPLS 3.0. Berikut hasil dari uji Q-Square pada Tabel 6.

Tabel 6. Hasil Uji Q-Square

\begin{tabular}{lc}
\hline \multicolumn{1}{c}{ Variabel } & Q-Square \\
\hline Loyalitas & 0.438 \\
Kepercayaan & 0.415 \\
Niat Pembelian & 0.405 \\
\hline
\end{tabular}

Hasil pengujian Q-Square pada Tabel 6. Diatas menunjukan hasil Q-Square untuk variabel dependen niat pembelian dalam penelitian ini adalah 0.405 , hasil variabel ndependent loyalitas sebesar 0.438 , dan hasil variabel kepercayaan adalah 0.415 . Maka dari itu, model penelitian ini dikatakan relevan dikarenakan memiliki nilai yang lebih besar dari nol $\left(\mathrm{Q}^{2}>0\right)$.

\section{Hasil Uji Goodness of Fit (GoF)}

Pengujian selanjutnya adalah Goodness of Fit (GoF), pengujian ini dilakukan untuk mengevaluasi kecocokan model dari keseluruhan prediksi model. Pengujian ini dilakukan secara manual dengan rumus : 


$$
\begin{aligned}
& \sqrt{\sqrt{\overline{A V E} \times \overline{R^{2}}}} \\
& \begin{array}{ll}
\text { Maka perhitungannya menjadi : } \\
\text { Total AVE } & =(0.611+0.677+0.689+0.676+0.661+0.746)=4.06 \\
\text { Total } \mathrm{R}^{2} & =(0.662+0.649+0.591)=1.902 \\
\text { GoF } & =\sqrt{4.06 \times 1.902}=2.779
\end{array}
\end{aligned}
$$

Pada hasil pengujian GoF diatas, nilai ini termasuk kedalam kategori GoFLarge karena memiliki nilai diatas 0.36. Maka dari itu, model penelitian ini memiliki kecocokan model penelitian yang besar.

\section{HASIL UJI HIPOTESIS}

Analisis ini terdiri dari Path Coefficient Analysis, Signifikansi ( $p$-Value), dan $\mathrm{f}^{2}$ (Effect Size Analysis). Hipotesis H1 sampai H10 dapat didukung jika path coefficient memiliki nilai yang berkisar antara -1 sampai +1 dan nilai yang terdapat dari signifikansi ( $p$-Value) lebih kecil dari 0.05 (<0.05). Pengujian moderator yang terdapat di hipotesis H10 dilakukan uji-t dengan taraf signifikansi yang digunakan sebesar 0.05. Jika t hitung lebih kecil dari t tabel, maka H0 ditolak dan jika Ha diterima, maka variabel secara parsial mempunyai pengaruh yang signifikan.

\section{Hasil Uji Path Coefficient dan Significance Test (p-Value)}

Berikut merupakan hasil dari perhitungan path coefficient dan significance test, serta pengujian bootstrapping.

Tabel 7. Hasil Uji Path Coefficient dan Significance Test

\begin{tabular}{cccc}
\hline Variabel & Path Coefficient & t-Statistic & p-Value \\
\hline Consumer Use of Social Media $\rightarrow$ Trust & 0.308 & 3.461 & 0.001 \\
Consumer Use of Social Media $\rightarrow$ Loyalty & 0.185 & 1.731 & 0.084 \\
Company Generated Communication $\rightarrow$ Trust & 0.342 & 4.587 & 0.000 \\
Company Generated Communication $\rightarrow$ Loyalty & 0.277 & 2.431 & 0.015 \\
User Generated Communication $\rightarrow$ Trust & 0.241 & 2.902 & 0.004 \\
User Generated Communication $\rightarrow$ Loyalty & 0.200 & 2.437 & 0.015 \\
Trust $\rightarrow$ Loyalty & 0.250 & 2.058 & 0.002 \\
Trust $\rightarrow$ Purchase Intention & 0.492 & 5.348 & 0.000 \\
Loyalty $\rightarrow$ Purchase Intention & 0.322 & 3.352 & 0.001 \\
\hline
\end{tabular}




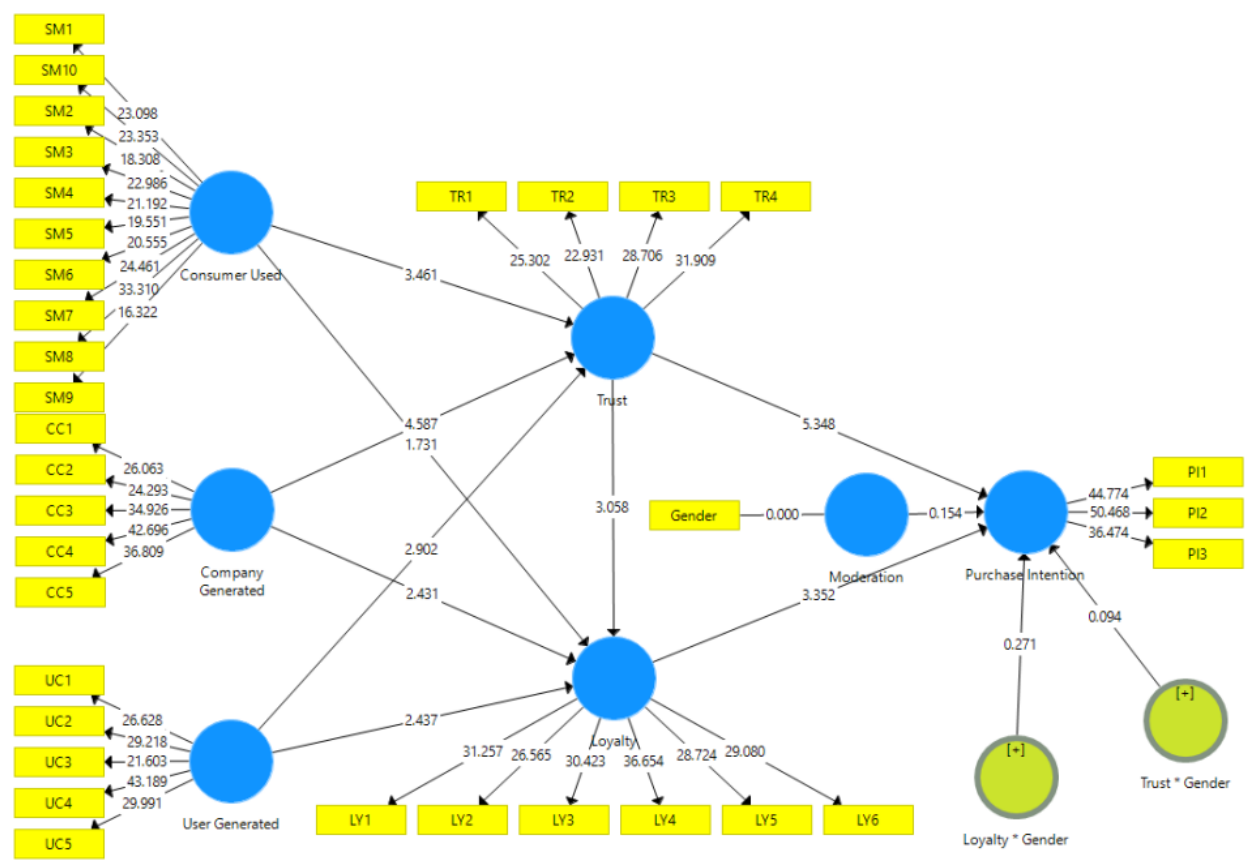

Gambar 1. Hasil Pengujian Bootstrapping

\section{Hasil Pengujian Effect Size Analysis ( $\left.\mathbf{f}^{2}\right)$}

Tabel 8 yang menampilkan hasil dari f-Square. Dapat disimpulkan bahwa keakuratan variabel consumer use of social media, company generated communication, user generated communication, trust, loyalty, dan niat pembelian memiliki efek yang lemah dikarenakan nilai effect size lebih besar dari 0.02 , tetapi tidak melebihi nilai 0.15 yang menunjukan efek yang sedang.

\section{Tabel 8. Hasil Pengujian Effect Size $\left(\mathrm{f}^{2}\right)$}

\begin{tabular}{cc}
\hline Variabel & Effect Size $\left(\mathbf{f}^{\mathbf{2}}\right)$ \\
\hline Consumer Use of Social Media $\rightarrow$ Trust & 0.108 \\
Consumer Use of Social Media $\rightarrow$ Loyalty & 0.037 \\
Company Generated Communication $\rightarrow$ Trust & 0.117 \\
Company Generated Communication $\rightarrow$ Loyalty & 0.071 \\
User Generated Communication $\rightarrow$ Trust & 0.071 \\
User Generated Communication $\rightarrow$ Loyalty & 0.047 \\
Trust $\rightarrow$ Loyalty & 0.065 \\
Trust $\rightarrow$ Purchase Intention & 0.144 \\
Loyalty $\rightarrow$ Purchase Intention & 0.070 \\
\hline
\end{tabular}

\section{Hasil Analisis Moderasi}

Dalam penelitian ini analisis moderasi menggunakan perangkat lunak SmartPLS. Moderasi yang digunakan adalah gender. Dapat dilihat pada Tabel 9 nilai path coefficient, p-Value, dan tStatistic.

Tabel 9. Hasil Analisis Moderasi

\begin{tabular}{ccccc}
\hline Variabel & Path Coefficient & $\boldsymbol{f}^{\mathbf{2}}$ & t-Statistic & p-Value \\
\hline Trust $\rightarrow$ Purchase Intention $*$ Gender & -0.015 & 0.000 & 0.094 & 0.925 \\
Loyalty $\rightarrow$ Purchase Intention * Gender & 0.050 & 0.001 & 0.271 & 0.787 \\
\hline
\end{tabular}

Berdasarkan hasil pengujian, moderasi gender yang digunakan untuk memoderasi kepercayaan terhadap niat pembelian memiliki pengaruh yang negatif dan tidak tidak signifikan. Seperti yang terlihat pada Tabel 9 diatas, variabel memiliki p-Value yang lewat dari batas maksimum sebesar 
$0.05(<0.05)$ dan t-Statistic sebesar 0.094 yang kurang dari 1.96 (t-stat $<\mathrm{t}$-tabel). Hal ini menunjukan variabel moderasi tidak memoderasi hubungan kepercayaan dengan niat pembelian. Lalu moderasi gender kedua yang digunakan untuk memoderasi loyalitas terhadap niat pembelian memiliki pengaruh yang positif, tetapi tidak signifikan. Dapat dilihat pada Tabel 9 diatas, variabel memiliki p-Value yang lewat dari batas maksimum sebesar $0.05(<0.05)$ dan tStatistic sebesar 0.271 yang kurang dari 1.96 (t-stat < t-tabel). Hal ini menunjukan variabel moderasi tidak memoderasi hubungan loyalitas dengan niat pembelian.

\section{DISKUSI}

Berdasarkan hasil uji hipotesis pertama, loyalitas pelanggan mampu memberi pengaruh positif, secara statistik signifikan pada niat pembelian di restoran SALADSTOP! di Jakarta, maka dapat disimpulkan bahwa $\mathrm{H} 1$ diterima. Hal ini sejalan dengan penelitian sebelumnya (Mainardes \& Cardoso, 2019; Hameed \& Kanwal, 2018; Panda et al., 2019) yang menyatakan bahwa loyalitas pelanggan memiliki pengaruh positif pada niat pembelian. Loyalitas membuat konsumen akan datang dan membeli kembali produk pada sebuah merek di masa depan atau kunjungan selanjutnya. Loyalitas juga memicu tumbulnya niat seseorang untuk membeli.

Hasil uji hipotesis kedua menemukan bahwa kepercayaan mampu memberi pengaruh positif, secara statistik signifikan pada niat pembelian di restoran SALADSTOP! di Jakarta. Maka dapat disimpulkan bahwa $\mathrm{H} 2$ diterima dan hal ini sejalan dengan penelitian sebelumnya (Mainardes \& Cardoso, 2019; Issock et al., 2019; Irshad et al. 2019) yang menyatakan bahwa kepercayaan memiliki pengaruh yang positif pada niat pembelian. Kepercayaan membuat konsumen percaya dengan sebuah perusahaan atau merek, dengan kepercayaan, calon konsumen juga dapat memiliki penilaian yang lebih terhadap sebuah perusahaan dan merek. Kepercayaan dapat muncul dari konsumen dikarenakan beberapa faktor, yang bisa diambil sebagai contoh adalah penggunaan media sosial.

Berdasarkan hasil uji hipotesis ketiga, kepercayaan mampu memberi pengaruh positif secara statistik signifikan pada loyalitas pelanggan di restoran SALADSTOP! di Jakarta. H3 diterima dan sesuai dengan penelitian sebelumnya (Mainardes \& Cardoso, 2019; Esenyel \& Girgen, 2019; Ebrahim, 2019; Issock et al., 2019; Kwon et al., 2020) yang menyatakan bahwa kepercayaan memiliki pengaruh yang positif pada loyalitas pelanggan. Dengan meningkatkan kepercayaan konsumen dengan perusahaan, ini akan memicu timbulnya loyalitas seseorang terhadap sebuah merek. Penelitian Alfian dan Sihombing (2021) pada konsumen Starbuck juga mendukung hasil penelitian ini. Saat memiliki kepercayaan akan merek, konsumen dapat menjadi loyal dengan merek tersebut sehingga mereka akan tetap membeli kembali ke merek tersebut, bahkan hingga merekomendasikan merek ke orang lain.

Pada uji hipotesis keempat, diperoleh bahwa penggunaan media sosial oleh konsumen mempu memberi pengaruh positif secara statistik signifikan pada kepercayaan di restoran SALADSTOP! di Jakarta. Hipotesis 4 diterima dan sejalan dengan penelitian sebelumnya (Mainardes \& Cardoso, 2019; Esenyel \& Girgen, 2019; Kwon et al., 2020) yang menyatakan bahwa penggunaan media sosial oleh konsumen memiliki pengaruh yang positif pada kepercayaan. Dengan meningkatkan penggunaan media sosial oleh konsumen, ini akan memicu timbulnya kepercayaan sesorang terhadap merek. Dengan kosumen menggunakan media sosial sebagai media untuk membagi dan memberi informasi terhadap pengguna media sosial lainnya, maka kepercayaan konsumen terhadap SALADSTOP! dapat meningkat. Dengan kosnumen membaca dan berinteraksi dengan konsumen SALADSTOP!, maka dapat timbulnya kepercayaan 
terhadap SALADSTOP! dikarenakan mendapatkan informasi dari konsumen yang sudah menggunakan atau membeli atau juga mengkonsumsi di restoran SALADSTOP!.

Hasil uji hipotesis kelima menunjukkan bahwa penggunaan media sosial oleh konsumen tidak mampu memberikan hasil yang positif secara statistik tidak signifikan terhadap loyalitas pelanggan SALADSTOP! di Jakarta. Maka dapat disimpulkan H5 ditolak. Temuan ini tidak sejalan dengan penelitian sebelumnya (Mainardes \& Cardoso, 2019; Esenyel \& Girgen, 2019; Kwon et al., 2020) yang menyatakan bahwa penggunaan media sosial oleh kosumen memiliki pengaruh yang positif pada loyalitas pelanggan. Konsumen yang tidak pernah melakukan transaksi sebelumnya di SALADSTOP! belum tentu dapat loyal dengan merek SALADSTOP! itu sendiri. Kepercayaan dapat timbul dari informasi yang dibaca di media sosial, tetapi belum tentu dapat memicu rasa loyalitas terhadap merek hanya dari pendapat konsumen di media sosial. Dibutuhkan faktor lain seperti kualitas atau kepuasan atau faktor lain yang dapat mempengaruhi loyalitas.

Berdasarkan hasil uji hipotesis keenam, komunikasi dari perusahaan mampu memberikan hasil yang positif secara statistik signifikan pada kepercayaan restoran SALADSTOP! di Jakarta. Hipotesis 6 diterima, dimana hasil ini sejalan dengan penelitian sebelumnya (Mainardes \& Cardoso, 2019; Ebrahim, 2019; Kwon et al., 2020) yang menyatakan bahwa komunikasi dari perusahaan di media sosial memiliki pengaruh yang positif pada kepercayaan. Dengan melakukan komunikasi dengan konsumen, perusahaan dapat meningkatkan tingkat kepercayaan konsumen dikalau SALADSTOP! ini baik untuk dikonsumsi atau baik untuk di beli. Perusahaan dapat membagikan hal-hal menarik yang SALADSTOP! lakukan untuk meningkatkan kepercayaan ini. Kepercayaan merupakan salah satu variabel penting yang dapat meningkatkan daya beli atau niat beli konsumen terhadap merek atau perusahaan.

Hipotesis ketujuh dalam penelitian ini diterima, komunikasi dari perusahaan di media sosial mampu memberikan hasil yang positif secara statistik signifikan pada loyalitas pelanggan restoran SALADSTOP! di Jakarta. Hasil ini sesuai dengan Ebrahim (2019) dan Nyadzayo et al., (2019) yang menyatakan bahwa komunikasi dari perusahaan di media sosial memiliki pengaruh yang positif pada loyalitas pelanggan. Dengan perusahaan melakukan komunikasi dengan pelanggannya, maka dapat timbul rasa loyalitas terhadap perusahaan tersebut atau sebuah merek. Perusahaan yang selalu sedia untuk melakukan komunikasi dengan pelanggannya, dapat dikatakan perusahaan yang peduli dengan pelanggannya.

Berdasarkan hasil hipotesis kedelapan, komunikasi dari pengguna media sosial mampu memberikan hasil yang positif secara statistik signifikan pada kepercayaan restoran SALADSTOP! di Jakarta. Seperti halnya dengan penelitian Mainardes \& Cardoso (2019), Sohail et al., (2020) dan Zhang \& Li (2019) yang menyatakan bahwa komunikasi dari pengguna media sosial memiliki pengaruh yang positif pada kepercayaan, Hipotesis 8 dalam penelitian ini diterima. Dengan banyaknya pengguna media sosial, maka informasi pada jaman sekarang ini akan dengan mudah dan cepat tersebar. Komunikasi merupakan salah satu kegiatan penting untuk menarik konsumen. Komunikasi yang baik dapat menambah konsumen dan menarik perhatian mereka.

Komunikasi dari pengguna di media sosial mampu memberikan hasil yang positif secara statistik signifikan pada loyalitas pelanggan restoran SALADSTOP! di Jakarta. Maka dapat disimpulkan H9 diterima dan hal ini juga sesuai dengan penelitian sebelumnya (Sohail et al., 2020; Nyadzayo, 2019). Pengguna media sosial memiliki ruang luas untuk berkomunikasi dengan 
ribuan atau jutaaan orang yang menggunakan media sosial. Dengan komunikasi yang baik, hal ini dapat memicu rasa loyalitas yang dimiliki oleh konsumennya SALADSTOP!.Ini dapat meningkatkan sara loyal terhadap restoran dikarenakan pengguna media sosial dapat membagikan pengalaman, atau komentar mereka terhadap SALADSTOP!.

Berdasarkan hasil pengujian hipotesis kesepuluh, kepercayaan dan loyalitas pelanggan yang dimoderasi gender tidak memiliki pengaruh yang positif secara statistik pada niat pembelian restoran SALADSTOP! di Jakarta. Maka dapat disimpulkan H10 ditolak. Hal ini tidak sesuai dengan penelitian Benson et al. (2018), Beccera \& Badrinarayan (2013), serta Jeon \& Jeong (2016) yang menyatakan bahwa kepercayaan dan loyalitas pelanggan yang dimoderasi gender memiliki pengaruh yang positif pada niat pelanggan. Hal ini dapat terjadi dikarenakan tidak terdapat perbedaan niat pembelian yang dimiliki oleh kelompok pria maupun wanita dalam penelitian ini, sehingga perbedaan gender tidak memiliki pengaruh moderasi dalam pengaruh kepercayaan pada niat pembelian maupun pengaruh loyalitas pelanggan pada niat pembelian.

\section{KESIMPULAN DAN SARAN}

Kesimpulan yang dapat diambil pada penelitian ini adalah bahwa kepercayaan dapat mempengaruhi loyalitas pelanggan dan niat pembelian. Loyalitas pelanggan dapat mempengaruhi niat pembelian. Penggunaan media sosial oleh konsumen tidak dapat mempengaruhi loyalitas pelanggan, namun dapat mempengaruhi kepercayaan. Selanjutnya, komunikasi dari perusahaan di media sosial dan komunikasi dari pengguna di media sosial juga dapat mempengaruhi kepercayaan dan loyalitas pelanggan. Selain itu, kepercayaan dan loyalitas pelanggan yang dimoderasi gender tidak memiliki pengaruh terhadap niat pembelian.

Peneliti menyarankan agar perusahaan dapat mempertahankan dan meningkatkan kepercayaan pelanggannya agar bisa mempertahankan dan meningkatkan niat pembelian. Pemilik restoran sejenis SALADSTOP! dapat menjaga loyalitas pelanggan dengan tetap mempertahankan kualitas merek dan produknya. Di masa mendatang, penelitian selanjutnya dapat menambahkan variabel lain seperti persepsi atas hidup sehat maupun persepsi atas harga sebagai variabel independen yang mungkin dapat membentuk niat pembelian konsumen pada restoran yang menyajikan makanan sehat.

\section{Ucapan Terima Kasih (Acknowledgement)}

Peneliti mengucapkan terima kasih kepada LPPM Universitas Tarumanagara atas pendanaan penelitian melalui skema Hibah Penelitian Tugas Akhir Periode 1 tahun 2021.

\section{REFERENSI}

Alfian, C. \& Sihombing, S.O. (2021). Anteseden loyalitas merek: Studi empiris pada konsumen Starbucks. Jurnal Muara Ilmu Ekonomi dan Bisnis, 5 (1): hlm 99-110. https://10.24912/jmieb.v5i1.10056.

Becerra, E.P., \& Badrinarayanan, V. (2013). The influence of brand trust and brand identification on brand evangelism. Journal of Product \& Brand Management, 22(5/6), 371-383. https://doi.org/10.1108/jpbm-09-2013-0394

Benson, V., Ezingeard, J., \& Hand, C. (2019). An empirical study of purchase behaviour on social platforms. Information Technology \& People, 32(4), 876-896. https://doi.org/10.1108/itp-08-2017-0267

Chakraborty, D. (2019). Factors responsible for making young urban consumers brand loyal: A study on mobile network operators. Journal of Management Development, 38(7), 616-636. https://doi.org/10.1108/JMD-01-2019-0029 
Ebrahim, R. S. (2019). The role of trust in understanding the impact of social media marketing on brand equity and brand loyalty. Journal of Relationship Marketing, 19(4), 287-308. https://doi.org/10.1080/15332667.2019.1705742

Esenyel, I., \& Girgen, M. (2019). Customer interactions on social media and their impact on trust and loyalty: The moderating role of product learning. Management Science Letters, 14971506. https://doi.org/10.5267/j.msl.2019.5.003

Hameed, S., \& Kanwal, M. (2018). Effect of brand loyalty on purchase intention in cosmetics industry. Research in Business and Management, 5(1), 25. https://doi.org/10.5296/rbm.v5i1.12704

Tunjungsari, H.K. (2019). Pengaruh Kemasan Terhadap Minat Beli Masyarakat Dengan Kualitas Sebagai Variabel Mediasi Pada Produk "Legit". Jurnal Manajemen Bisnis dan Kewirausahaan, 2(6). https://doi.org/10.24912/jmbk.v2i6.4908

Irshad, M., Ahmad, M. S., \& Malik, O. F. (2020). Understanding consumers' trust in social media marketing environment. International Journal of Retail \& Distribution Management, 48(11), 1195-1212. https://doi.org/10.1108/ijrdm-07-2019-0225

Issock Issock, P. B., Roberts-Lombard, M., \& Mpinganjira, M. (2020). The importance of customer trust for social marketing interventions: A case of energy-efficiency consumption. Journal of Social Marketing, 10(2), 265-286. https://doi.org/10.1108/jsocm$\underline{05-2019-0071}$

Jeon, M. M., \& Jeong, M. (2017). Customers' perceived website service quality and its effects on E-loyalty. International Journal of Contemporary Hospitality Management, 29(1), 438457. https://doi.org/10.1108/ijchm-02-2015-0054

Kwon, J., Jung, S., Choi, H., \& Kim, J. (2020). Antecedent factors that affect restaurant brand trust and brand loyalty: Focusing on US and Korean consumers. Journal of Product \& Brand Management, ahead-of-print(ahead-of-print). https://doi.org/10.1108/jpbm-02$\underline{2020-2763}$

Mainardes, E. W., \& Cardoso, M. V. (2019). Effect of the use of social media in trust, loyalty and purchase intention in physical stores. The International Review of Retail, Distribution and Consumer Research, 29(4), 456-477. https://doi.org/10.1080/09593969.2019.1583593

Nyadzayo, M. W., Johnson, L. W., \& Rossi, M. (2020). Drivers and outcomes of brand engagement in self-concept for luxury fashion brands. Journal of Fashion Marketing and Management: An International Journal, 24(4), 589-609. https://doi.org/10.1108/jfmm-052018-0070

Oliver, R. L. (1999). Whence consumer loyalty? Journal of Marketing, 63, 33-44. https://doi.org/10.1177/00222429990634s105

Palmatier, R. W., L. K. Scheer, and J.-B. E. M. Steenkamp. 2007. "Customer Loyalty to Whom? Managing the Benefits and Risks of Salesperson-Owned Loyalty." Journal of Marketing Research 44 (2): 185-199. doi:10.1509/jmkr.44.2.185.

Panda, T. K., Kumar, A., Jakhar, S., ～Luthra, S., Garza-Reyes, J. A., Kazancoglu, I., \& Nayak, S. S. (2020). Social and environmental sustainability model on consumers' altruism, green purchase intention, green brand loyalty and evangelism. Journal of Cleaner Production, 243, 118575. https://doi.org/10.1016/j.jclepro.2019.118575

Poulis, A., Rizomyliotis, I., \& Konstantoulaki, K. (2018). Do firms still need to be social? Firm generated content in social media. Information Technology \& People.

Rapp, A., L. S. Beitelspacher, D. Grewal, and D. E. Hughes. 2013. "Understanding Social Media Effects across Seller, Retailer, and Consumer Interactions." Journal of the Academy of Marketing Science 41 (5): 547-566. doi:10.1007/s11747-013-0326-9. 
Schivinski, B., and D. Dabrowski. 2015. "The Impact of Brand Communication on Brand Equity through Facebook." Journal of Research in Interactive Marketing 9 (1): 31-53. doi:10.1108/JRIM02-2014-0007.

Sohail, M. S., Hasan, M., \& Sohail, A. F. (2020). The impact of social media marketing on brand trust and brand loyalty. International Journal of Online Marketing, 10(1), 15-31. https://doi.org/10.4018/ijom.2020010102

Srivastava, S. C., S. Chandra, and Y. L. Theng. 2010. "Evaluating the Role of Trust in Consumer Adoption of Mobile Payment Systems: An Empirical Analysis." Communications of the Association for Information Systems 27: 561-588.

Thakur, R. (2016). Understanding customer engagement and loyalty: A case of mobile devices for shopping. Journal of Retailing and Consumer Services, 32, 151-163. https://doi.org/10.1016/j.jretconser.2016.06.004

Zhang, C., \& Li, Y. (2019). How social media usage influences B2B customer loyalty: Roles of trust and purchase risk. Journal of Business \& Industrial Marketing, 34(7), 1420-1433. https://doi.org/10.1108/jbim-07-2018-0211 